\title{
Non-temporal dan and the grammar of $\mathrm{V} 2^{*}$
}

\author{
Liliane Haegeman (Dialing, Ghent University) \\ Andreas Trotzke (University of Konstanz; Autonomous University of Barcelona)
}

\begin{abstract}
This paper discusses a pattern in which a finite verb is preceded by a locative PP which combines with an initial or final occurrence of the adverb dan ('then') and which may look like a violation of the V2 constraint. The paper is relevant in the context of how to handle what look like exceptions to the V2 pattern, a point that is sometimes neglected in the formal literature though Zwart (2008a) draws attention to the importance of also capturing such recalcitrant data. Based on standard arguments for constituency, it will be shown that the adverb, which has a non-temporal reading, and the associated PP form one constituent. Thus, a pattern that might at first appear to be a violation of $\mathrm{V} 2$ in fact is shown to be in line with the constraint.
\end{abstract}

Keywords: verb second, Dutch, non-temporal dan, constituency

\section{Starting point: verb second}

The empirical focus of our contribution is a phenomenon referred to in the literature as V2 transgressions (Catasso 2015), patterns in which the verb second (V2) constraint unexpectedly seems to be flouted. The descriptive label 'V2' covers the descriptive generalization that in languages like Dutch the finite verb of the root clause tends to occupy the linearly second position, being preceded by one constituent. V2 has received a lot of attention in the literature, and is relevant on a number of theoretical dimensions, as illustrated by papers in Nederlandse Taalkunde such as Zwart (2008a,b), Barbiers, Koeneman, and Lekakou (2010), Den Dikken (2010b) and Postma (2011).

The material in this paper was presented at the workshop Particles in German, English and beyond, Saarland University, on January 21, 2019 and at the Annual meeting of the LAGB at QMUL, September 9-12, 2019. We thank both audiences for their feedback. Special thanks are due to Marcel den Dikken, Patrick Grosz, Marieke Meelen, Coppe van Urk and two anonymous reviewers for the present volume for insightful comments on the presentations and our paper. Of course, we are solely responsible for the way we have handled their comments. Andreas Trotzke gratefully acknowledges financial support from the Beatriu de Pinós program (Generalitat de Catalunya/Secretariat for Universities and Research of the Ministry of Economy and Knowledge; grant no. 2017-BP00031). 


\subsection{Verb second}

The analysis of V2 interacts with and impacts on various theoretical developments. As shown by Den Besten (1983), for instance, the emergence of the binary branching structure, according to which clauses display the hierarchy of binary projections in (1a), seems particularly adapted to capture the alternation between verb final subordinate clauses (1b) and verb second root clauses (1c): in the former, the conjunction dat ('that') fills the $\mathrm{C}$ position and in the latter, the finite verb heeft ('has') occupies C and one constituent is located in SpecCP:

(1) a. $\mathrm{CP}>\mathrm{TP}>\mathrm{VP}$

b. [СР [С dat] [тр Jan gisteren een nieuwe wagen gekocht heeft]] that Jan yesterday a new car bought has

c. [СР Gisteren [C heeft] [тр Jan een nieuwe wagen gekocht]]. yesterday has Jan a new car bought

With further theoretical developments came Rizzi's (1997) proposal that the CP layer of the clause should be decomposed into an array of functional heads, including heads encoding those discourse functional properties that are syntactically relevant such as Top or Foc. This development obviously raised the question as to how to capture the V2 restriction: if an array of distinct projections is available to host fronted constituents, as illustrated in English (2b), why are the same projections apparently not simultaneously available in V2 languages such as Dutch (2c)? This issue was tackled, among others, in the articles in Nederlandse Taalkunde listed above.

(2) a. ForceP $>$ TopP $>$ FocP $>$ TopP $>$ TopP $>$ FinP

b. [TopP Baked beans [FocP on no account [Foc Will] [FinP I eat again]]].

c. * [TopP Bonen in tomatensaus [FocP in geen geval [Foc Zal [FinP ik eten]]]. beans in tomato-sauce on no account will I eat 


\subsection{V2 transgressions}

The issue we are interested in here is V2 transgressions (Catasso 2015), i.e. patterns in which a regular V2 language displays patterns that seem to defy the V2 restriction. Such 'exceptional

patterns' have been noted and their importance for the full account of the V2 has been underlined. For instance, Zwart (2008a: 214) says: "de beschrijving van V2 is niet volledig als deze op zich onverwachte feiten niet op hun plaats vallen," i.e. the description of V2 is not complete if these unexpected facts do not find their place.

One well-known V2 transgression is the pattern referred to as Contrastive Left Dislocation (CLD) in Dutch (3), in which a left-peripheral constituent precedes a V2 clause containing a resumptive constituent: (3a) is a schematic representation, (3b) illustrates the pattern with the subject Jan resumed by the pronoun die, and in (3c) an initial adjunct is resumed by the resumptive temporal adverbial dan.

\begin{tabular}{|c|c|c|c|c|}
\hline a. & XP, [CP d-resumptive & [C Vfin] $[$ те & & $\ldots]]$ \\
\hline b. & [CP die & [C mag $][\mathrm{TP}$ & niet & uitnodigen]]. \\
\hline & Jan & may & you & invite \\
\hline c. & En op de tweede dag, & {$[\mathrm{CP}$ dan } & [c gaan $][$ тР & we naar Gent]]. \\
\hline & and on the second day & then & go & we to Ghent \\
\hline
\end{tabular}

As suggested by the bracketing in (3), one approach to these patterns is to consider the initial constituent as a 'satellite' (Koster 1978), i.e. a 'main clause external' (in the sense of Broekhuis and Corver 2016: 1679-1733), or 'extra cyclic' (in the sense of Zwart 2005) constituent. On this assumption, the V2 transgressions in (3) can be reconciled with the V2 constraint: being extra-sentential, the initial constituent falls outside the realm of the narrow syntax and does not count for the calculation of V2, which is governed by the narrow syntax.

While CLD in (3) is accepted by all Dutch speakers, other V3 transgressions are subject to regional or individual variation. The patterns in (4) illustrate such variation: (4a), signaled among others in Vanacker (1977) and discussed in terms of the generative framework by Zwart (2008a: 199), remains typically restricted to the (West) Flemish varieties of Dutch: an adjunct is followed by a full-fledged V2 root clause without a resumptive constituent being present in the latter. (4b) (first described in Vanacker 1980 and signaled in Zwart 2005) to the best of our 
knowledge is typical of the Ghent variety: an adjunct is followed unexpectedly by the formative die, a demonstrative pronoun, while the expected resumptive would be dan (3c).
a. Zonder entwat
te zeggen
Wansje
loat zen zwiins achter
without something
to say
Wansje
leaves his pigs behind

(Oostende, Winkler 1974: 364; Zwart 2008: 199 [4])

$\begin{array}{lllll}\text { b. Volgende } & \text { vrijdag } & \text { die } & \text { komt hij terug. } \\ \text { next } & \text { Friday } & \text { die } & \text { comes he back }\end{array}$

Zwart $(1997,2008 a)$ reconciles the pattern in (4a) with the V2 requirement in terms of Rizzi's (1997) articulated left periphery; for Haegeman and Greco (2018) the initial adjunct in (4a) is extra-sentential along the lines of Broekhuis and Corver (2016). We refer to the papers cited for discussion. Adopting Rizzi's (1997) articulated left periphery, De Clercq and Haegeman (2018) reinterpret (4b) as a regular V2 pattern. We refer to their paper for discussion.

In this paper we turn to a pattern briefly discussed in Zwart (2005: 288).

\section{Non-temporal dan and the left periphery}

\subsection{Starting point}

(5a) illustrates the use of the temporal adverb dan as an initial constituent in a V2 clause, (5b) shows the adverb in medial position. In this use, dan is near-equivalent to daarna ('thereafter'), its function is to link one event to another preceding event.

$\begin{array}{llllll}\text { a. } & \text { (En) dan } & \text { gaan } & \text { we naar Gent. } \\ \text { (and) then } & \text { go } & \text { we to } & \text { Ghent } \\ \text { b. } & \text { (En) we } & \text { gaan dan naar Gent. } \\ & \text { (and) we } \text { go then to } & \text { Ghent. }\end{array}$

The data in (6) seem to illustrate a V2 transgression: what at first sight looks like the same temporal adverbial dan combines with a locative PP naast the kerk ('next to the church'). In 
(6a) dan precedes the locative PP, in (6b) it follows it. ${ }^{1}$ In (6), dan has a non-temporal reading and it is not equivalent to daarna; it has a sequencing function, linking a location with a preceding step when a route is being described.
a. (En) dan naast de kerk
(and) then next the church
woont mijn tante.
lives my aunt
b. (En) naast de kerk dan woont mijn tante.

Mentioning non-temporal dan, Zwart (2005: 28) briefly discusses (7) (his [42b]), with a locative PP in dezelfde landstreek ('in the same area') followed by non-temporal $n u$ ('now'). That the adverb $n u$ receives a non-temporal reading is shown by the fact that while the adverb $n u$ ('now') encodes the present time, its clausal context in (7) is past time. For Zwart (2005), $n u$ in (7) is 'extra-dependent'. Though the concept of extra-dependency is not defined in great detail in his paper, and no genuine diagnostics are given to detect extra-dependency, Zwart (2005) seems to analyze extra-dependent elements as interpolations.

$\begin{array}{lllll}\text { In dezelfde } & \text { landstreek nu waren herders. } \\ \text { in the-same } & \text { area } & \text { now were shepherds }\end{array}$

'Now there were shepherds in that same countryside.'

We add that a similar pattern is discussed in recent work by van der Wouden $(2015,2019$, this volume), who refers to the pattern as 'the Barabbas construction'. His conclusions, based on a much wider range of particles that seem to lead to V3 linear orders are rather different from ours: Van der Wouden (this volume) suggests that in apparent V3 root clauses in Dutch with a particle preceding the finite verb, the particle occupies a Wackernagel position.

\subsection{Goal}

This paper will offer a descriptive inventory of the distributive properties of non-temporal dan in (6), in which we show that non-temporal dan is a co-constituent of the adjacent locative PP, and thus we can conclude that the pattern does not violate the V2 constraint.

\footnotetext{
${ }^{1}$ A first impression is that Flemish speakers may be slightly more tolerant of non-temporal dan in (6) than speakers originating from the Netherlands, but we do not have precise data to back this up. It is unclear which factors might underlie the variation across speakers.
} 


\section{Against a resumption analysis of final dan}

One argument for treating the sequence of $d a n+\mathrm{PP}$ in (6) as a constituent is that it is the preverbal string in a V2 pattern. However, for (6b), in which dan follows the PP, one might envisage the alternative analysis according to which, rather than being a co-constituent with the PP, dan is a resumptive element, and that the pattern we find is basically a CLD pattern, similar to that in (3c) with resumptive temporal dan, as schematized in (8):



However, a dislocation analysis for final dan in $(6 \mathrm{~b})$ is implausible.

(i) Regular dislocated constituents such as op de tweede dag in (3c) can be followed by an intonation break (indicated by the comma). This is not available with non-temporal dan.

(ii) In CLD, the resumptive matches the dislocated constituent such that, for instance, temporal adjuncts are resumed by dan for present or future adjuncts and by toen for past adjuncts, and locative adjuncts are resumed by daar ('there'). Crucially, dan cannot resume a locative adjunct $(9 \mathrm{c})$ :

(9)
a. En op de tweede dag,
dan/*daar
gaan we
naar Gent. and on the second day, then $/ *$ there go we to Ghent
b. En op de tweede dag, toen $/ *$ dan $/ *$ daar gingen we naar Gent. and on the second day, then $/ *$ then $/ *$ there went we to Ghent
c. (En) [naast de kerk], daar $/ *$ toen $/ *$ dan woont mijn tante. and next-to the church /there/ then/*then lives my aunt

(iii) In CLD, resumptive temporal dan, temporal toen and locative daar can be focused by juist ('just'), as in (10). Such focusing is not available with non-temporal dan.
just then and on the second day,
a. En op de tweede dag, juist dan
gaan we
naar Gent.
go we
to Ghent
b. En op de tweede dag, juist toen and on the second day, just then
gingen we naar Gent.
c. (En) [naast de kerk],
juist daar
went we to Ghent and next-to the church just there woont mijn tante. lives my aunt 
(iv) As shown in (11), non-temporal final dan itself combines with a CLD pattern in which a dislocated PP (naast de kerk 'next to the church') is resumed by locative daar, in two configurations: either dan follows the dislocated PP (11a) or it follows the resuming locative daar (11b). Assuming that daar is the designated resumptive for locatives, analyzing non-temporal dan as a resumptive entails that (11) instantiates a dual resumption.

(11)
a. (En) naast de kerk dan, daar woont
mijn tante.
(and) next the church then, there lives
my aunt
b. (En) naast de kerk, daar dan woont
mijn tante.
(and) next the church, there then lives
my aunt

\section{Split PPs and intrusive dan}

While it might be conceivable that dan and an adjacent locative PP do not constitute a constituent in (6), with initial or final dan, this analysis is unlikely for what we label 'intrusive dan', a pattern in which dan is sandwiched between a preposition and its R-pronoun complement.

In Dutch, a pronominal PP-complement takes the form of an R-pronoun (daar, er 'there'), it usually shifts to the left of P (van Riemsdijk 1978). ${ }^{2}$
a. *naast het/er/daar
next it/there/there
b. daar/er naast
there/er next

2 Though in directional source-goal PPs both hier and daar seem to remain in the complement position of the source (van) or goal (naar) preposition. We do not pursue this point here, it falls outside the scope of the paper.

$\begin{array}{lllll}\text { (i) a. } & \text { van } & \text { daar } & \text { tot } & \text { daar } \\ & \text { from } & \text { there } & \text { to } & \text { there } \\ \text { b. } & \text { van } & \text { hier } & \text { naar } & \text { daar } \\ & \text { from } & \text { here } & \text { to } & \text { there }\end{array}$


In locative PPs with R-complements, non-temporal dan may be initial (13a), final (13b), or 'intrusive' (13c). (14) are attested examples of intrusive dan.
a. (En) dan daar/er naast
woont mijn tante.
(and) then there next
lives my aunt
b. (En) daar/ernaast dan
woont mijn tante.
c. (En) daar/er dan naast
woont mijn tante

(14)



A PP containing an R-pronoun can be the focus of a pseudo-cleft sentence (15), including PPs featuring intrusive dan (15c). This again suggests that the string containing dan is a constituent. Observe, however, that in (15) non-temporal dan itself cannot constitute the focus of the cleft: the focal element is the preposition naast.
a. Waar (dat) mijn tante woont
is [daar naast dan]. where (that) my aunt lives
is there next then
b. Waar (dat) mijn tante woont
is [dan daar naast].
where (that) my aunt lives
is then there next
c. Waar (dat) mijn tante woont
is [daar dan naast].
where (that) my aunt lives
is there then next 


\section{Distribution of the constituent containing non-temporal dan}

\subsection{Embedding}

PPs containing non-temporal dan, including those with intrusive dan, can be the complement of a preposition, as shown in (16) and (17):

$\begin{array}{lll}\text { a. Ik } & \text { heb die lamp } & \text { gekocht } \\ \text { I } & \text { have that lampshade } & \text { bought } \\ \text { [voor } & \text { [dan naast die tafel] }] .^{3} & \\ \text { for } & \text { then next that table } & \end{array}$
b. [Voor [dan naast die tafel]] heb ik die lamp gekocht. for then next that table have I that lampshade bought

\begin{tabular}{|c|c|c|c|c|c|c|c|}
\hline (17) & $\mathrm{Ik}$ & heb & dat & gekocht & [voor & [daar dan & naast]]. \\
\hline & I & have & that & bought & for & there then & next \\
\hline b. & [Voor & [daar & dan & naast]] heb & $\mathrm{ik}$ & die lamp & gekocht. \\
\hline & for & there & then & next have & I & that lampshade & bought \\
\hline
\end{tabular}

PPs containing non-temporal dan may be embedded in a nominal constituent $(18 \mathrm{a}, \mathrm{b})$, see Corver (1990: 37-38).

(18) a. [Het bureau [daar dan naast] is voor de doctoraatsstudenten. the office there then next is for the PhD-students

b. De doctoraatsstudenten kan je vinden

the PhD-students $\quad$ can you find
[in [het bureau [daar dan naast]]].
in the office there then next

\footnotetext{
${ }^{3}$ An anonymous reviewer for this paper who accepts non-temporal dan in general finds the examples in (16) hard to accept while accepting those in (17). This confirms that there is variation among speakers and suggests that the acceptability of the patterns may depend on a number of factors.
} 
The PP with non-temporal dan may function as the predicate of a met ('with') small clause:

(19) a. Er was een landhuis [met nog een cottage er/?daar (dan) naast]. there was a manor with PART a cottage there (then) next

b. Er was een landhuis [met er/?daar (dan) naast nog een cottage]. there was a manor with there (then) next PART a cottage

\subsection{Extraposition}

PPs containing non-temporal dan may be extraposed: in (20) the extraposed constituent is an adjunct, in (21) it is associated with a nominal. ${ }^{4}$ Assuming that extraposition is structuredependent, then this would confirm that dan forms a constituent with the PP.

$\begin{array}{lllllll}\text { a. Ze hebben nog } & \text { een } & \text { huis gehad [dan daar } & \text { naast]. } \\ \text { they } & \text { have PART a } & \text { house had then there } & \text { next } \\ \text { b. Ze hebben nog } & \text { een } & \text { huis gehad [daar dan } & \text { naast]. } \\ & \text { they have PART a } & \text { house had there then next }\end{array}$
a. De doctoraatsstudenten kan je in het bureau the PhD-students can you in the office vinden [dan daar naast]. find then there next

b. De doctoraatsstudenten kan je in het bureau the PhD-students can you in the office vinden [daar dan naast]. find there then next

c. De doctoraatsstudenten kan je in thet bureau
the PhD-students
can you in the office
vinden [daar naast dan]. find there next then

\footnotetext{
${ }^{4}$ An anonymous reviewer for this article finds (20) and (21) "strange." For Liliane Haegeman they are fully acceptable, with possibly the (a) examples slightly less good than the (b) and (c) examples.
} 


\section{Conclusion and issues for further research}

\subsection{Non-temporal dan and V2}

The arguments lined up above show that not only intrusive non-temporal dan but also PP initial or PP final non-temporal dan forms a constituent with the PP. This means that (6a) and (6b), which might appear problematic for the V2 generalization, turn out not to be a problem because, since dan and the PP are one constituent, (6) is in line with regular V2 patterns: the finite verb is preceded by just one constituent.

The question, of course, arises as to the internal structure of the dan-containing PP. Ultimately, any analysis will depend on one's theoretical position. We refer to Trotzke and Haegeman (2019) for one proposal, which combines the cartographic articulation of the internal structure of PPs as in Koopman (2000), Den Dikken (2010a), Aelbrecht and Den Dikken (2013), and Broekhuis and Dikken (2018), among many others, with recent work on discourse particles (as in Bayer and Trotzke 2015). Caution is needed, though, in formulating analytical hypotheses because, as shown in the next section, PPs are not the only constituents that may host nontemporal dan.

\subsection{Extending the empirical data}

While Trotzke and Haegeman (2019) formulate an analysis for the syntax of the PP which accommodates the distribution of non-temporal dan, including its distribution related to focusing juist ('just'), a point not discussed here, it should be pointed out that non-temporal dan can also display its sequencing function in other contexts, such as, for instance, in a nominal projection. (22) contains some illustrations of non-temporal dan in the nominal domain. We hasten to add that additional patterns are possible which, for reasons of space, we cannot discuss here. In (22a) and in (22b), a string consisting of the nominal de jongste zoon ('the youngest son') in combination with non-temporal dan forms the first constituent of a V2 clause. In (22c), non-temporal dan is associated with the possessor die man, which is doubled by the possessive pronoun zijn. In (22d), non-temporal dan precedes the definite determiner associated with the nominal zoon; it is preceded by the R-pronoun complement of the 
prepositional van, a pattern reminiscent of the PP-internal intrusive dan pattern discussed in Section $4 .^{5}$
a. De jongste zoon dan is getrouwd met mijn zus. the youngest son dan is married with my sister
b. (en) dan de jongste zoon is getrouwd met mijn zus. and then the youngest son is married with my sister
c. Die man dan zijn jongste zoon is getrouwd met mijn zus. that man then his youngest son is married with my sister
d. Daar dan de jongste zoon van is getrouwd met mijn zus. there then the youngest son of is married to my sister

The ultimate analysis of the syntax of non-temporal dan should obviously also capture those data.

\section{References}

Aelbrecht, Lobke \& Marcel den Dikken (2013). Preposition doubling in Flemish and its implications for the syntax of Dutch PPs. The Journal of Comparative Germanic Linguistics 16, 33-68.

Barbiers, Sjef, Koeneman, Olaf \& Marika Lekakou (2010). Vragen aan de linkerperiferie. Nederlandse Taalkunde 15, 284-307.

Bayer, Josef \& Andreas Trotzke (2015). The derivation and interpretation of left peripheral discourse particles. In: Josef Bayer, Roland Hinterhölzl \& Andreas Trotzke (eds.), Discourse-oriented syntax. Amsterdam: John Benjamins, 13-40.

Besten, Hans den (1983/89). On the interaction of root transformations and lexical deletive rules. In Werner Abrahams (ed.), On the formal syntax of the Westgermania. Amsterdam: John Benjamins, 47-131. Reprinted in Hans den Besten. (1989). Studies in Westgermanic syntax. PhD dissertation Katholieke Universiteit Brabant. Amsterdam \& Atlanta, GA: Rodopi.

\footnotetext{
${ }^{5}$ For movement of R-pronouns in the nominal domain, see Corver (1990: 37-8).
} 
Broekhuis, Hans \& Norbert Corver (2016). Syntax of Dutch. Verbs and verb phrases. Volume 3: Chapter 14: Main clause-external elements. Amsterdam: Amsterdam University Press. http://www.oapen.org/.

Broekhuis, Hans \& Marcel den Dikken (2018). Tot (aan) het einde ((aan) toe): The internal syntax of a Dutch complex PP. Glossa 3 (104), 1-19.

Catasso, Nicholas (2015). On postinitial aber and other syntactic transgressions: some considerations on the nature of V2 in German. Journal of Germanic Linguistics 27 (4), 317-365.

Corver, Norbert (1990). The syntax of left branch extractions. PhD dissertation Tilburg University.

De Clercq, Karen \& Liliane Haegeman (2018). The typology of V2 and the distribution of pleonastic DIE in the Ghent dialect. Frontiers in Psychology. https://doi.org/10.3389/fpsyg.2018.01342.

Den Dikken, Marcel (2010a). On the functional structure of locative and directional PPs. In: Guglielmo Cinque \& Luigi Rizzi (eds.), Mapping spatial PPs. Oxford: Oxford University Press, 74-126.

Den Dikken, Marcel (2010b). De linkerperiferie antwoordt. Nederlandse Taalkunde 15, 308309.

Haegeman, Liliane \& Ciro Greco (2018). West Flemish V3 and the interaction of syntax and discourse. The Journal of Comparative Germanic Linguistics, 21, 1-56.

Koopman, Hilda (2000). Prepositions, postpositions, circumpositions, and particles. In Hilda. Koopman (ed.), The syntax of specifiers and heads. London: Routledge, 204-260.

Koster, Jan (2000). Extraposition as parallel construal. Ms, University of Groningen.

Postma, Gertjan (2011). Het verval van het pronomen $d u$. Dialectgeografie en de historische syntaxis. Nederlandse Taalkunde 16, 56-87.

Riemsdijk, Henk van (1978). A case study in syntactic markedness: the binding nature of prepositional phrases. Dordrecht: Foris.

Rizzi, Luigi (1997). The fine structure of the left periphery. In: Liliane Haegeman (ed.), Elements of grammar. Dordrecht: Kluwer, 281-337.

Trotzke, Andreas \& Liliane Haegeman (2019). PP-internal particles in Dutch as evidence for PP-internal discourse structure. Particles in German, English and beyond, Saarland University, January 21, 2019. 
Vanacker, Valère F. (1977). Syntactische overeenkomsten tussen Frans-Vlaamse en Westvlaamse dialekten. In: De Franse Nederlanden. Les Pays Bas français. Jaarboek. Ons Erfdeel, 206-216.

Vanacker, Valère F. (1980). Een Vlaams adverbiaal steuntje. In: Joep Kruijsen (ed.), Liber Amicorum Weijnen, Een bundel opstellen aan Prof. dr. A. Weijnen bij zijn zeventigste verjaardag. Assen: Van Gorcum, 73-78.

van der Wouden, Ton (2015). A marked construction to mark a marked phenomenon: how to shift topics in Dutch, or, the Barabbas construction. In: Sander Lestrade, Peter de Swart, \& Lotte Hogeweg (eds.), Addenda: artikelen voor Ad Foolen, Radboud Universiteit Nijmegen, 539-572.

van der Wouden, Ton (2019). Uit kracht dan van de bevoegdheid. neerlandistiek.nl, 15 oktober 2019.

van der Wouden, Ton (this volume). Er is nog steeds geen partikelwoordenboek, hoewel echter het partikelonderzoek niet stilligt

Velde, John te (2013). West Germanic left-dislocated adverbial clauses: the role of the semantic interface. Interdisciplinary Journal for Germanic Linguistics and Semiotic Analysis 18, 163-206.

Vries, Mark de (2009). The left and right periphery in Dutch. The Linguistic Review 26, 291327.

Zwart, Jan-Wouter (1997). Morphosyntax of verb movement. A Minimalist Approach to the Syntax of Dutch. Dordrecht: Kluwer.

Zwart, Jan-Wouter (2005). Verb Second as a function of Merge. In: Marcel den Dikken \& Christina Tortora (eds.), The function of function words and functional categories. Amsterdam: John Benjamins, 11-40.

Zwart, Jan-Wouter (2008a). Verb-second als speelbal van de grammaticatheorie. Nederlandse Taalkunde 13, 198-216.

Zwart, Jan-Wouter (2008b). Naschrift. Nederlandse Taalkunde 13, 220-225.

\section{About the author(s)}

Liliane Haegeman, DiaLing, Ghent university

Liliane.haegeman@UGent.be

Andreas Trotzke, University of Konstanz, Autonomous University of Barcelona andreas.trotzke@uni-konstanz.de 